\title{
cagE as a biomarker of the pathogenicity of Helicobacter pylori
}

\author{
Ivy Bastos Ramis ${ }^{[1]}$, Júlia Silveira Vianna ${ }^{[2]}$, Lande Vieira da Silva Junior ${ }^{[2],}$ \\ Andrea Von Groll ${ }^{[2]}$ and Pedro Eduardo Almeida da Silva ${ }^{[1],[2]}$
}

[1]. Centro de Desenvolvimento Tecnológico, Universidade Federal de Pelotas, Pelotas, RS. [2]. Laboratório de Biologia Molecular, Universidade Federal do Rio Grande, Rio Grande, RS.

\begin{abstract}
Introduction: Helicobacter pylori infection is associated with gastro-duodenal diseases. Genes related to pathogenicity have been described for $\mathrm{H}$. pylori and some of them appear to be associated with more severe clinical outcomes of the infection. The present study investigates the role of $\operatorname{cag} E$ as a pathogenicity biomarker of $H$. pylori compare it to cagA, vacA, ice $A$ and babA2 genes and correlate with endoscopic diagnoses. Methods: Were collected biopsy samples of 144 dyspeptic patients at the Hospital of the Federal University of Rio Grande, Rio Grande do Sul, Brazil. After collection, the samples were sent for histological examination, DNA extraction and detection of all putative pathogenicity genes by PCR. Results: Of the 144 patients undergoing endoscopy, 57 (39.6\%) presented H. pylori by histological examination and PCR by detection of the ureA gene. Based on the endoscopic diagnoses, $45.6 \%$ (26/57) of the patients had erosive gastritis, while $54.4 \%(31 / 57)$ had enanthematous gastritis. The genes cagA, cagE, vacAs $1 / \mathrm{m} 1, v a c A s 1 / \mathrm{m} 2$ and iceAl were related to erosive gastritis, while the genes vacAs $2 / \mathrm{m} 2$, ice $A 2$ and $b a b A 2$ were associated to enanthematous gastritis. We found a statistically significant association between the presence of $c a g E$ and the endoscopic diagnosis. However, we detect no statistically significant association between the endoscopic diagnosis and the presence of $\operatorname{cag} A, v a c A$, ice $A$ and $b a b A 2$, although a biological association has been suggested. Conclusions: Thus, $\operatorname{cag} E$ could be a risk biomarker for gastric lesions and may contribute to a better evaluation of the $H$. pylori pathogenic potential and to the prognosis of infection evolution in the gastric mucosa.
\end{abstract}

Keywords: Helicobacter pylori. Pathogenicity genes. Endoscopic diagnosis.

\section{INTRODUCTION}

Helicobacter pylori, a microorganism adapted to colonize the gastric mucosa, is considered to be the main etiological agent of enanthematous gastritis (inflammation of the gastric epithelium with simple change mucosal), erosive gastritis (inflammation with loss of integrity of the epithelial lining, not exceeding the muscular layer of the mucosa) and also a risk factor for peptic ulcer and gastric cancer in humans $\mathbf{s}^{1,2}$. Factors related to the genetic polymorphism of the host, the diversity of bacterial pathogenicity and the environment seem to be related to the broad clinical spectrum related to infection by $H$. pylori ${ }^{3}$. Several putative genes, such as $\operatorname{cag} A, \operatorname{cag} E$, vacA, ice $A$ and $b a b A 2$, have been identified and are likely to play an important role in the pathogenicity of the bacterium ${ }^{4-8}$.

The cag-PAI is composed of approximately 31 genes, which are responsible for coding type IV secretion system components and inject effector molecules in the host cell. The presence of

Address to: Dr. Pedro Eduardo Almeida da Silva. Lab. Biologia Molecular/ FURG. Rua General Osório s/n, 96200-190 Rio Grande, RS, Brasil.

Phone: 5553 3233-8895; Fax: 5553 3233-8863

e-mail: pedrefurg@gmail.com

Received 22 November 2012

Accepted 07 February 2013
cag-PAI affects the inflammatory state of the gastric mucosa by polymorphonuclear cell infiltration and increases the production of interleukin-8 (IL-8) ${ }^{1}$.cagA gene (cytotoxin associated gene A) is considered to be the cag-PAI marker. $\operatorname{cag} A$ positive strains tend to be more pathogenic, produce more severe lesions of the epithelium and increase the expression of interleukin- $1 \beta$ and IL- $8^{9,10}$. Another member of the cag-PAI, the cagE gene (cytotoxin associated gene $E$ ), is also related to an increased production of IL-8 in the gastric epithelial cells ${ }^{11}$.

The vacA gene encodes the vacuolating cytotoxin that damages the gastric epithelial cells. It comprises two variable parts: the $s$-region, which encodes the signal peptide with the slor $s 2$ allele, and the $m$-region (middle) with the $m 1$ or $m 2$ allele ${ }^{6,12}$. The mosaic combination of the $s$ and $m$ region alleles determines the production of the vacuolating cytotoxin and is associated with the pathogenicity of the bacterium ${ }^{13}$. In general, vacAs $1 / \mathrm{m} 1$ and $s 1 / \mathrm{m} 2$ strains produce high and moderate levels of vacuolating toxin, respectively, whereas the $s 2 / m 2$ strains produce little or no toxin ${ }^{12}$. The vacAsl/ml genotype is considered to be associated with more severe pathologies ${ }^{14}$.

The ice $A$ gene (induced by contact with the epithelium) has two main allelic variants, designated iceAland iceA2. The iceAlallele is up-regulated by the contact of $H$. pylori with gastric epithelial cells and has been associated with peptic ulcer disease. Meanwhile, the iceA2 allele has been related to asymptomatic gastritis and non-ulcer dyspepsia ${ }^{7,15}$. 
The $b a b A$ gene (blood-group antigen-binding adhesin) encodes a membrane protein, an adhesion called BabA, which binds to the Lewisb blood group antigen on the gastric epithelial cells $^{8,16}$. Although three $b a b$ alleles have been identified ( $b a b A 1$, $b a b A 2$ and $b a b B)$, only the $b a b A 2$ gene product is necessary for the Lewisb binding activity. Thus, $b a b A 2$ is responsible for pathogenicity, allowing contact between bacterium and gastric epithelium and facilitating the release of other pathogenicity factors ${ }^{11}$.

We hypothesized that the clinical outcomes of $H$. pylori infection were influenced by the distribution of the abovementioned pathogenic factors; therefore, this study aimed at investigating the role of $\operatorname{cag} E$ as a pathogenicity biomarker of $H$. pylori-positive patients, compare it to cagA, vacA, iceA and $b a b A 2$ genes and correlate these findings with endoscopic diagnoses.

\section{METHODS}

\section{Patients and clinical samples}

In this study were included 144 patients with dyspeptic symptoms submitted to upper gastrointestinal endoscopy between October 2008 and March 2009 in the Integrated Center for Gastroenterology at the Hospital of the Federal University of Rio Grande, Rio Grande do Sul, Brazil. Patients that had recently (within the last 15 days) received antibiotics or non-steroidal anti-inflammatory drugs (NSAIDs) or had been treated for H. pylori or gastrointestinal bleeding in the last seven days, were excluded. The presence of $H$. pylori infection in the subjects was determined by histological examination and detection of the ureA gene by polymerase chain reaction (PCR).

\section{Endoscopic diagnosis}

The endoscopic diagnosis was established in accordance to the Sydney System classification ${ }^{17}$.

\section{Histological examination}

The biopsy samples of the gastric antrum and body destined for histology were fixed in formalin and stained with Hematoxylin-Eosin (H\&E) and Giemsa. Histological classification of gastritis was established according to the Sydney System ${ }^{18}$.

\section{Extraction of DNA}

After collection, the biopsy samples of the gastric antrum and body were kept in Brain Heart Infusion Broth (Acumedia ${ }^{\circledR}$, United States of America) with $20 \%$ glycerol and stored at $-70{ }^{\circ} \mathrm{C}$ for further DNA extraction. DNA was extracted of the biopsy samples using DNAzol ${ }^{\circledR}$ Reagent (Invitrogen ${ }^{\mathrm{TM}}$, United States of America) and $10 \mu \mathrm{g} / \mu \mathrm{L}$ proteinase K (Promega, United States of America). The samples were separated from the broth and re-suspended in $100 \mu \mathrm{L}$ of proteinase $\mathrm{K}$ and $500 \mu \mathrm{L}$ of DNAzol ${ }^{\circledR}$ Reagent. The mixture was incubated at $55^{\circ} \mathrm{C}$ for $3 \mathrm{~h}$ and, after this period, $500 \mu \mathrm{L}$ of DNAzol® Reagent was added to it again. After centrifugation at $14,000 \mathrm{~g}$ for $10 \mathrm{~min}$, the supernatant was collected and $500 \mu \mathrm{L}$ cold absolute ethanol was added, followed by centrifugation at $12,000 \mathrm{~g}$ for $10 \mathrm{~min}$, after which the supernatant was discarded. The DNA pellet was washed two times with $800 \mu \mathrm{L}$ of $75 \%$ ethanol, air dried and re-suspended in $50 \mu \mathrm{L}$ of $8 \mathrm{mM} \mathrm{NaOH}$. The DNA was stored at $-20^{\circ} \mathrm{C}$ until further usage.

\section{Detection of the ure $A$ gene}

The detection of the ureA gene was used to confirm the H. pylori infection in all of the patients ${ }^{19}$. PCRwas performed as described by Rota et $\mathrm{al}^{20}$.

\section{Detection of pathogenicity genes by PCR}

The presence of the $\operatorname{cag} A$ gene was investigated by the amplification of the constant region near the $3^{\prime}$ end of the cagA. The PCR was performed as proposed by Rota et al. ${ }^{20,21}$. and the $\operatorname{cag} E$ gene was investigated according to Sozzi et al. ${ }^{22}$. The presence of the vacA and iceA alleles in the biopsy samples was investigated using the primers previously described ${ }^{23,24}$ and the PCR was conducted as proposed by Benenson et $\mathrm{al}^{25}$. For detection of the $b a b A 2$ gene, the primers and the PCR conditions applied, were described by Sheu et al. ${ }^{26}$.

\section{Statistical analysis}

The chi-square test was used for the analysis of categorical data. $P$-values of less than 0.05 of a two-tailed test were considered statistically significant. The analyses were performed using the software Statistica 10.

\section{Ethical considerations}

This study was approved by the Research Ethics Committee of the Health Area (FURG process number 23116.003335/200843) and carried out in accordance with the ethical standards outlined in the Helsinki Declaration. A written informed consent was obtained from all the patients.

\section{RESULTS}

From the 144 patients who underwent endoscopy, $57(39.6 \%)$ presented $H$. pylori under histological examination and PCR, of these 40 were women and 17 were men with an average age of 46.2 years (range, 14-74 years). Based on the endoscopic diagnoses, $45.6 \%$ (26/57) of the patients had erosive gastritis, while $54.4 \%(31 / 57)$ had enanthematous gastritis.

The distribution of the $c a g A, c a g E, v a c A$, ice $A$ and $b a b A 2$ genes in relation to the endoscopic diagnoses is described in Table 1. A statistically significant association was found between the $\operatorname{cag} E$ gene and the diagnosis of erosive gastritis $(\mathrm{p}=0.029)$. However, between the $c a g A, v a c A, i c e A$ and babA2 genes and the clinical manifestations, no statistically significant association was observed, although a biological significance was suggested.

The presence of the cagA gene was significantly correlated with the $\operatorname{cag} E$ gene $(\mathrm{p}<0.001)$ and only two $\operatorname{cag} A$-positive samples did not present the cagE gene (Table 2). A statistically significant association was also observed between the presence of $\operatorname{cag} A, \operatorname{cag} E$ and vacA genes versus babA2 $(\mathrm{p}<0.05)$ 
TABLE 1 - Distribution of the $v a c A, \operatorname{cag} A, \operatorname{cag} E$, ice $A$ and $b a b A 2$ genes in gastric biopsy samples from patients with different gastric disorders

\begin{tabular}{|c|c|c|c|c|}
\hline \multirow[b]{2}{*}{ Genotype } & \multicolumn{2}{|c|}{$\begin{array}{l}\text { Enanthematous gastritis } \\
\qquad(\mathrm{n}=31)\end{array}$} & \multicolumn{2}{|c|}{$\begin{array}{c}\text { Erosive gastritis } \\
\qquad(\mathrm{n}=26)\end{array}$} \\
\hline & $\mathrm{n}$ & $\%$ & $\mathrm{n}$ & $\%$ \\
\hline \multicolumn{5}{|l|}{$\operatorname{vac} A^{a}$} \\
\hline vacAsl $1 / m 1(\mathrm{n}=15)$ & 6 & 40.0 & 9 & 60.0 \\
\hline $\operatorname{vacAs} 1 / m 2(\mathrm{n}=10)$ & 4 & 40.0 & 6 & 60.0 \\
\hline $\operatorname{vacAs} 2 / m 1(\mathrm{n}=1)$ & 1 & 100.0 & - & \\
\hline vacAs $2 / m 2(\mathrm{n}=12)$ & 10 & 83.3 & 2 & 16.7 \\
\hline vacA-negative $(\mathrm{n}=19)$ & 10 & 52.6 & 9 & 47.4 \\
\hline \multicolumn{5}{|l|}{$\operatorname{cag} \mathrm{A}^{\mathrm{b}}$} \\
\hline $\operatorname{cag} A$-positive $(\mathrm{n}=26)$ & 11 & 42.3 & 15 & 57.7 \\
\hline $\operatorname{cag} A$-negative $(\mathrm{n}=31)$ & 20 & 64.5 & 11 & 35.5 \\
\hline \multicolumn{5}{|l|}{$\mathrm{cagE}^{\mathrm{c}}$} \\
\hline $\operatorname{cag} E$-positive $(\mathrm{n}=24)$ & 9 & 37.5 & 15 & 62.5 \\
\hline $\operatorname{cag} E$-negative $(\mathrm{n}=33)$ & 22 & 66.7 & 11 & 33.3 \\
\hline \multicolumn{5}{|l|}{$i_{c e} A^{d}$} \\
\hline iceAl $(\mathrm{n}=11)$ & 4 & 36.4 & 7 & 63.6 \\
\hline iceA2 $(\mathrm{n}=30)$ & 17 & 56.7 & 13 & 43.3 \\
\hline iceA-negative $(\mathrm{n}=16)$ & 10 & 62.5 & 6 & 37.5 \\
\hline \multicolumn{5}{|l|}{ babA2 $2^{e}$} \\
\hline babA2-positive $(\mathrm{n}=32)$ & 19 & 59.4 & 13 & 40.6 \\
\hline babA2-negative $(\mathrm{n}=25)$ & 12 & 48.0 & 13 & 52.0 \\
\hline
\end{tabular}

${ }^{\mathrm{a}} \mathrm{p}$-value of the Chi-square test $=0.136 ;{ }^{b}$-value of the Chi-square test $=0.094 ;{ }^{c}$-value of the Chi-square test $=0.029 ;{ }^{\mathrm{d}} \mathrm{p}$-value of the Chi-square test $=0.381 ;{ }^{\mathrm{e}} \mathrm{p}$-value of the Chi-square test $=0.392$.

(Table 3). We evaluated the distribution of genes in all patients. The combination $\operatorname{cag} A / \operatorname{cag} E$ was detected in $62.5 \%(15 / 24)$ and $37.5 \%(9 / 24)$ of patients with erosive and enanthematous gastritis, respectively. The biomarkers cagA/cagE/babA2/ vacAs $1 \mathrm{~m} 1 /$ iceAlcombined was present in $15.4 \%(4 / 26)$ of patients with erosive gastritis. In patients with enanthematous gastritis, the combination babA2/vacAs $2 \mathrm{~m} 2 /$ ice $A 2$ was detected in $22.6 \%(7 / 31)$. Among patients $H$. pylori-positive, $28.1 \%$ $(16 / 57)$ did not show any of the biomarkers studied here.

\section{DISCUSSION}

Helicobacter pylori infection has been related to severe gastroduodenal diseases. There is an increasing evidence that the presence of $H$. pylori genes and their different genotypic combinations are related to development of gastric diseases ${ }^{11}$.

The cagA gene was detected in $57.7 \%(15 / 26)$ of gastric biopsy samples from patients with erosive gastritis. This gene has often been associated with the apoptosis of T helper type 1 (Th1) cells, increased IL-8 production, increased inflammation in the gastric mucosa and a higher risk for developing peptic ulcers or gastric cancers ${ }^{27}$.
TABLE 2 - Relationship between $\operatorname{cag} A$ and $\operatorname{cag} E$ genes in gastric biopsy samples

\begin{tabular}{lcc}
\hline Genotype & $\begin{array}{c}c a g E-\text { positive } \\
(\mathrm{n}=24)\end{array}$ & $\begin{array}{c}c a g E-\text { negative } \\
(\mathrm{n}=33)\end{array}$ \\
\hline cagA - positive $(\mathrm{n}=26)$ & $92.3 \%(24 / 26)$ & $7.7 \%(2 / 26)$ \\
cag $A-$ negative $(\mathrm{n}=31)$ & $0 \%(0 / 31)$ & $100 \%(31 / 31)$ \\
\hline $\mathrm{p}$ value of the Chi-square test $<0.001$. & &
\end{tabular}

TABLE 3 - Relationship between the $c a g A, c a g E$ and $v a c A$ genes versus $b a b A 2$ in gastric biopsy samples

\begin{tabular}{|c|c|c|}
\hline Genotype & $\begin{array}{c}\text { babA2 - positive } \\
(\mathrm{n}=32)\end{array}$ & $\begin{array}{c}\text { babA2 - negative } \\
(\mathrm{n}=25)\end{array}$ \\
\hline \multicolumn{3}{|l|}{$\operatorname{cag} \mathrm{A}^{\mathrm{a}}$} \\
\hline $\operatorname{cag} A-$ positive $(\mathrm{n}=26)$ & $80.8 \%(21 / 26)$ & $19.2 \%(5 / 26)$ \\
\hline $\operatorname{cag} A-$ negative $(\mathrm{n}=31)$ & $35.5 \%(11 / 31)$ & $64.5 \%(20 / 31)$ \\
\hline \multicolumn{3}{|l|}{$\operatorname{cag} E^{b}$} \\
\hline $\operatorname{cag} E$ - positive $(\mathrm{n}=24)$ & $79.2 \%(19 / 24)$ & $20.8 \%(5 / 24)$ \\
\hline $\operatorname{cag} E-$ negative $(\mathrm{n}=33)$ & $39.4 \%(13 / 33)$ & $60.6 \%(20 / 33)$ \\
\hline \multicolumn{3}{|l|}{$\operatorname{vac}^{\mathrm{c}}$} \\
\hline vacAsl/ml $(\mathrm{n}=15)$ & $73.3 \%(11 / 15)$ & $26.7 \%(4 / 15)$ \\
\hline vacAs $1 / m 2(\mathrm{n}=10)$ & $90.0 \%(9 / 10)$ & $10.0 \%(1 / 10)$ \\
\hline $\operatorname{vacAs} 2 / m 1(\mathrm{n}=1)$ & $100.0 \%(1 / 1)$ & - \\
\hline $\operatorname{vac} A s 2 / m 2(\mathrm{n}=12)$ & $83.3 \%(10 / 12)$ & $16.7 \%(2 / 12)$ \\
\hline$v a c A$-negative $(\mathrm{n}=19)$ & $5.3 \%(1 / 19)$ & $94.7 \%(18 / 19)$ \\
\hline
\end{tabular}

${ }^{a}$-value of the Chi-square test $<0.001 ;{ }_{p}$-value of the Chi-square test $=0.003$;

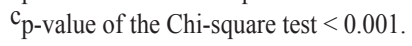

On the other hand, the $\operatorname{cag} E$ gene was identified in $62.5 \%$ $(15 / 24)$ of gastric biopsy samples from patients with erosive gastritis. This study found a statistically significant association between $\operatorname{cag} E$ and erosive gastritis, a more severe mucosal injury. This may be due to the fact that this gene is directly connected with an increase in the production of IL-8 in the gastric cells and with the intensity of epithelial damage ${ }^{28}$.

When evaluating the effect of the combination of genes with the type of gastritis, the presence of the cagA/cagE combination in patients with erosive gastritis was $62.5 \%(15 / 24)$. In patients with enanthematous gastritis, this combination was detected in $37.5 \%(9 / 24)$. The relation between the variables was statistically significant $(\mathrm{p}=0.047)$. These results permit to infer that $\operatorname{cag} E$ is an important marker of pathogenicity alone or combined with $\operatorname{cag} A$.

Concerning the vacA gene, the combination $s 1 / \mathrm{ml}$ was mostly detected in gastric biopsy samples derived from patients with an endoscopic diagnosis of erosive gastritis. However, the combination $s 2 / m 2$ of the $v a c A$ gene was frequently observed in samples from patients with enanthematous gastritis. In general, vacAs $1 / \mathrm{m} 1$ strains have been linked with higher degrees of inflammation and cell infiltration when compared to vacAs2/ $m 2$ strains $^{29,30}$. Furthermore, vacAs $1 / m 1$ strains produce large 
amounts of vacuolating toxin and induce a higher vacuolating activity in gastric epithelial cells than vacAs $2 / m 2$ strains ${ }^{12,31}$.

Regarding the iceA gene, the iceAl allele was more commonly found in samples from patients with erosive gastritis (63.6\%), whereas the ice $A 2$ allele was more commonly identified in specimens from patients with enanthematous gastritis (56.7\%), but no statistically significant association was observed. A previous study demonstrated that iceAl expression was significantly related to the host mucosal response, which led to the hypothesis that the levels of transcription within the host environment may contribute to disease development. In contrast, ice 2 expression may be more influenced by the gene structure, which has a repeated protein structure but is not homologous with known proteins?

A statistically significant association was observed between cagA, cagE, vacA genes and babA2 ( $<<0.05)$ (Table 3), but other authors did not find any association between these pathogenicity genes in the samples they investigated ${ }^{23,32,33}$. Our data, however, supports the relationship between the genes $\operatorname{cag} A, \operatorname{cag} E, v a c A$ and $b a b A 2$ that was described in previous reports $^{34-37}$.

The association of biomarkers cagA/cagE/babA2/vacAs $1 \mathrm{ml} /$ iceAl was detected in $15.4 \%$ (4/26) of patients with erosive gastritis, this is such an important evidence, considering that these genotypes are more pathogenic. Similar percentages were found by studies conducted in Colombia and in Brazil. In the latter, only the ice $A$ gene was discordant ${ }^{38,39}$. In patients with enanthematous gastritis, the combination of babA2/vacAs $2 \mathrm{~m} 2 /$ ice $A 2$ was detected in $22.6 \%(7 / 31)$. In a previous study in southern Brazil, the vacAs2m2 and iceA2 alleles were also related with enanthematous gastritis ${ }^{40}$.

According to the results, we concluded that the detection of $H$. pylori is not in itself sufficient to assess the development of gastric mucosal damage, but the presence of pathogenicity genes is able to give such information. Although the small number of samples can be a limitation in this study, these findings highlight the importance of the detection of biomarkers to evaluate the need of treatment for the microorganism eradication, since in some cases the elimination can lead to the development of other pathologies such as gastric esophageal reflux, asthma and obesity ${ }^{41}$. The $\operatorname{cag} E$ gene can be used as a risk biomarker for gastric lesions contributing to a better assessment of the pathogenic potential of $H$. pylori and for the infection prognosis of the gastric mucosa.

\section{ACKNOWLEDGMENTS}

We thank Dr. Ernani Pinho de Moraes and Dra. Marcia Fernandes by collecting samples; Dr. Obirajara Rodrigues and Dr. Carlos Renan Varela Juliano for the histological analysis.

\section{CONFLICT OF INTEREST}

The authors declare that there is no conflict of interest.

\section{FINANCIAL SUPPORT}

This study was supported by the Fundação de Apoio ao Hospital de Ensino do Rio Grande (FAHERG), Coordenação de Aperfeiçoamento de Pessoal de Nivel Superior (CAPES) and Conselho Nacional de Desenvolvimento Científico e Tecnológico (CNPq).

\section{REFERENCES}

1. Godoy APO, Miranda MCB, Paulino LC, Mendonça S, Ribeiro ML, Pedrazzoli JRJ. Análise das impressões digitais de DNA e de fatores de virulência de linhagens de Helicobacter pylori. Arq Gastroenterol 2007; 44:107-112.

2. Miszputen SJ. Guias de Medicina Ambulatorial e Hospitalar UNIFESP. $2^{\text {rd }}$ ed. Barueri(SP): Manoli; 2007.

3. Kusters JG, Van Vliet AHM, Kuipers EJ. Pathogenesis of Helicobacter pylori Infection. Clin Microbiol Rev 2006;19:449-490.

4. Covacci A, Censini S, Bugnoli M, Petracca R, Burroni D, Macchia G, et al. Molecular characterization of the $128-\mathrm{kDa}$ immunodominant antigen of Helicobacter pylori associated with cytotoxicity and duodenal ulcer. Proc Natl Acad Sci USA 1993; 90:5791-5795.

5. Censini S, Lange C, Xiang Z, Crabtree JE, Ghiara P, Borodovsky M, et al. cag, a pathogenicity island of Helicobacter pylori, encodes type I-specific and disease-associated virulence factors. Proc Natl Acad Sci USA 1996; 93:14648-14653.

6. Cover TL. The vacuolating cytotoxin of Helicobacter pylori. Mol Microbiol 1996; 20:241-246.

7. Peek Jr RM, Thompson SA, Donahue JP, Tham KT, Atherton JC, Blaser MJ, et al. Adherence to gastric epithelial cells induces expression of a Helicobacter pylori gene, iceA, that is associated with clinical outcome. Proc Assoc Am Physicians 1998; 110:531-544.

8. Gerhard M, Lehn N, Neumayer N, Borén T, Rad R, Schepp W, et al. Clinical relevance of the Helicobacter pylori gene for blood-group antigen-binding adhesin. Proc Natl Acad Sci USA 1999; 96:12778-12783.

9. Bittencourt PFS, Rocha GA, Penna FJ, Queiroz DMM. Gastroduodenal peptic ulcer and Helicobacter pylori infection in children and adolescents. J Pediatr 2006; 82:325-334.

10. Blaser MJ, Berg DE. Helicobacter pylori genetic diversity and risk of human disease. J Clin Invest 2001; 107:767-773.

11. Lima VP, Rabenhorst SHB. Genes Associados à Virulência de Helicobacter pylori. Rev Bras Cancerologia 2009; 55:389-396.

12. Van Doorn L-J, Figueiredo C, Sanna R, Pena S, Midolo P, Ng EK, et al. Expanding allelic diversity of Helicobacter pylori vacA. J Clin Microbiol 1998; 36:2597-2603.

13. Cavalcante MQ, Silva CIS, Braga-Neto MB, Fialho ABC, Fialho AN, Barbosa AMC, et al. Helicobacter pylori vacA and cagA genotypes in patients from northeastern Brazil with upper gastrointestinal diseases. Mem Inst Oswaldo Cruz 2012; 107:561-563.

14. Van Doorn L-J, Figuereido C, Sanna R, Plaisier A, Schneeberger P, De Boer W, et al. Clinical relevance of the cagA, vacA, and iceA status of Helicobacter pylori. Gastroenterology 1998; 115:58-66.

15. Sampaio A, Santos P. Factores genéticos do Helicobacter pylori e do hospedeiro na carcinogénese gástrica. Rev Port Ciências Biomédicas 2008; 3:72-78.

16. Oliveira AG, Santos A, Guerra JB, Rocha GA, Rocha AMC, Oliveira CA, et al. babA2- and cagA-Positive Helicobacter pylori Strains Are Associated with Duodenal Ulcer and Gastric Carcinoma in Brazil. J Clin Microbiol 2003; 41:3964-3966

17. Tytgat GNJ. The Sydney System: Endoscopic Division. Endoscopic appearances in gastritis/duodenitis. J Gastroenterol Hepatol 1991; 6:223-234.

18. Price AB. The Sydney System: histological division. J Gastroenterol Hepatol $1991 ; 6: 209-222$. 
19. Clayton CL, Kleanthous H, Coates PJ, Morgan DD, Tabaqchali S. Sensitive detection of Helicobacter pylori by using polymerase chain reaction. J Clin Microbiol 1992; 30:192-200.

20. Rota CA, Pereira-Lima JC, Blaya C, Nardi NB. Consensus and variable region PCR analysis of Helicobacter pylori 3 region of $c a g A$ gene in isolates from individuals with or without peptic ulcer. J Clin Microbiol 2001; 39:606-612.

21. Bukanov NO, Berg DE. Ordered cosmid library and high-resolution physicalgenetic map of Helicobacter pylori strain NCTC 11638. Mol Microbiol 1994; 11:509-523.

22. Sozzi M, Tomasini ML, Vindigni C, Zanussi S, Tedeschi R, Basaglia G, et al. Heterogeneity of cag genotypes and clinical outcome of Helicobacter pylori infection. J Lab Clin Med 2005; 146:262-269.

23. Mattar R, Santos AF, Eisig JN, Rodrigues TN, Silva FM, Lupinacci RM, et al. No Correlation of babA2 with vacA and cagA Genotypes of Helicobacter pylori and Grading of Gastritis from Peptic Ulcer Disease Patients in Brazil. Helicobacter 2005; 10:601-608.

24. Yamaoka Y, Kodama T, Gutierrez O, Kim JG, Kashima K, Graham DY Relationship between Helicobacter pylori iceA, cagA and vacA status and clinical outcome: Studies in four different countries. J Clin Microbiol 1999; 37:2274-2279.

25. Benenson S, Halle D, Rudensky B, Faber J, Schlesinger Y, Branski D, et al. Helicobacter pylori Genotypes in Israeli Children: The Significance of Geography. J Pedriatr Gastroenterol Nutr 2002; 35:680-684.

26. Sheu BS, Sheu SM, Yang HB, Huang AH, Wu JJ. Host gastric Lewis expression determines the bacterial density of Helicobacter pylori in babA2 genopositive infection. Gut 2003; 52:927-932.

27. Boyanova L, Markovska R, Yordanov D, Marina M, Ivanova K, Panayotov S, et al. High prevalence of virulent Helicobacter pylori strains in symptomatic Bulgarian patients. Diagn Micr Infec Dis 2009; 64:374-380.

28. Ladeira MSP, Salvadori DMF, Rodrigues MAM. Biopatologia do Helicobacter pylori. J. Bras Patol Med Lab 2003; 39:335-342.

29. Nogueira C, Figueiredo C, Carneiro F, Gomes AT, Barreira R, Figueira P, et al. Helicobacter pylori genotypes may determine gastric histopathology. Am J Pathol 2001; 158:647-654.

30. Martins LC, Corvelo TCO, Demachki S, Araujo MTF, Assumpção MB, Vilar SCAJ, et al. Clinical and pathological importance of vacA allele heterogeneity and $\operatorname{cag} A$ status in peptic ulcer disease in patients from north Brazil. Mem Inst Oswaldo Cruz 2005; 100:875-881.
31. Letley DP, Atherton JC. Natural Diversity in the N Terminus of the Mature Vacuolating Cytotoxin of Helicobacter pylori Determines Cytotoxin Activity. J Bacteriol 2000; 182:3278-3280.

32. Gatti LL, Módena JLP, Payão SLM, Smith MAC, Fukuhara Y, Módena JLP, et al. Prevalence of Helicobacter pylori cagA, iceA and babA2 alleles in Brazilian patients with upper gastrointestinal diseases. Acta Trop 2006; 100:232-240.

33. Paniagua GL, Monroy E, Rodríguez R, Arroniz S, Rodríguez C, Cortés JL, et al. Frequency of vacA, cagA and babA2 virulence markers in Helicobacter pylori strains isolated from Mexican patients with chronic gastritis. Ann Clin Microbiol Antimicrob 2009; 8:1-6.

34. Erzin Y, Koksal V, Altun S, Dobrucali A, Aslan M, Erdamar S, et al. Prevalence of Helicobacter pylori vacA, cagA, cagE, ice A, babA2 Genotypes and Correlation with Clinical Outcome in Turkish Patients with Dyspepsia. Helicobacter 2006; 11:574-580.

35. Chiarini A, Calà C, Bonura C, Gullo A, Giuliana G, Peralta S, et al. Prevalence of virulence-associated genotypes of Helicobacter pylori and correlation with severity of gastric pathology in patients from western Sicily, Italy. Eur J Clin Microbiol Infect Dis 2009; 28:437-446.

36. Torres LE, Melián K, Moreno A, Alonso J, Sabatier CA, Hernández M, et al. Prevalence of vacA, cagA and babA2 genes in Cuban Helicobacter pylori isolates. World J Gastroenterol 2009; 15:204-210.

37. Boyanova L, Yordanov D, Gergova G, Markovska R, Mitov I. Association of iceA and babA genotypes in Helicobacter pylori strains with patient and strain characteristics. Antonie van Leeuwenhoek 2010; 98:343-350.

38. Galvis AA, Trespalacios-Rangel AA, Otero W, Mercado-Reyes MM, PoutouPiñales RA. Prevalence of cagA, vacA, babA2 and iceA Genes in $H$. pylori Strains Isolated from Colombian Patients with Functional Dyspepsia. Polish J Microbiol 2012; 61:33-40.

39. Garcia GT, Aranda KR, Gonçalves ME, Cardoso SR, Iriya K, Silva NP, et al. High prevalence of clarithromycin resistance and $\operatorname{cag} A$, vacA, ice $A 2$ and $b a b A 2$ genotypes of Helicobacter pylori in Brazilian children. J Clin Microbiol 2010; 48:4266-4268.

40. Ramis IB, Fonseca TL, Moraes EP, Fernandes MS, Mendoza-Sassi R, Rodrigues O, et al. Molecular Basis of pathogenicity in Helicobacter pylori clinical isolates. J Clin Microbiol 2010; 48:3776-3778.

41. Blaser M. Stop the Killing of beneficial bacteria. Nature 2011; 476:393-394. 